Relations industrielles

Industrial Relations

\title{
Exclusion of Unionized Workers from Employment Standards
}

Law

\section{L'exclusion des travailleurs syndiqués de la législation sur les normes minimales d'emploi}

\section{La exclusión de trabajadores sindicalizados de la normas legales del empleo}

\section{David B. Fairey}

\section{Volume 64, numéro 1, hiver 2009}

URI : https://id.erudit.org/iderudit/029541ar

DOI : https://doi.org/10.7202/029541ar

\section{Aller au sommaire du numéro}

Éditeur(s)

Département des relations industrielles de l'Université Laval

ISSN

0034-379X (imprimé)

1703-8138 (numérique)

Découvrir la revue

Citer cet article

Fairey, D. B. (2009). Exclusion of Unionized Workers from Employment Standards Law. Relations industrielles / Industrial Relations, 64(1), 112-133. https://doi.org/10.7202/029541ar

\begin{abstract}
Résumé de l'article
La législation sur les normes minimales d'emploi présente un seuil de protection pour les employés en deçà duquel les employeurs ne peuvent fixer les conditions de travail. Elle constitue ainsi un point de départ pour la négociation de conditions de travail, lorsque les salariés représentés par un syndicat négocient une convention collement de limiter les pratiques déloyales de concurrence sur les conditions de travail.
égal

En mai 2002, le gouvernement de la Colombie-Britannique, au Canada, a effectué un nombre important de modifications à sa législation sur les normes minimales de l'emploi, en prétendant lui donner plus de flexibilité et, par conséquent, la rendre plus avantageuse pour les salariés et les employeurs. Une des modifications les plus importantes apportée à cette loi consistait à exclure de ses dispositions principales tous les salariés couverts par des conventions collectives, si ces dernières contenaient quelque allusion à ces dispositions.

Les travailleurs syndiqués de la Colombie-Britannique avaient déjà été exclus des protections principales prévues à la loi sur les normes au cours de l'année 1983. Suite à une révision, au début des années 90, cette disposition a été infirmée au motif que les conventions collectives ne pouvaient exclure les parties de la protection fondamentale de la loi. Cependant, on a convenu qu'u certain degré de flexibilité serait introduit en autant que les conventions collectives dans leur ensemble rencontreraient ou

Les modifications apportées en 2002 à la loi ont rétabli les dispositions d'exclusion de 1983, dans des termes plus vastes et génerraux. En ce faisant, elles ont encouragé les parties à s'exclure de la loi et elles ont induit en erreur les travailleurs syndiqu

Une des conséquences de ces modifications de 2002 est à l'effet de permettre à des unions collaboratrices ou en collusion ave des employeurs de négocier ouvertement des ententes se situant en deçà des normes de protection prevues par la loi. La une organisation impliquée dans la régulation des rapports du travail, et qui doit entre autres éléments essentiels être dotée d'une constitution adoptée par ses membres et ne pas être dominée par un employeur ou sous l'influence de ce dernier. La Colombie-Britannique a historiquement abritée un petit nombre de syndicats « alternatifs » délaissant la confrontation, qui sont apparus sur la scène quand les employeurs opposaient une resistance aux efforts de syndicalisation des syndicats. Ces syndicats ont signé des ententes de reconnaissance volontaire avec les employeurs qui se situaient en deçà des normes de l'industrie. Cet essai effectue une révision des conventions collectives signées par l'Association chrétienne du travail du Canada (CLAC), le syndicat alternatif le plus important au plan de l'accommodement avec les employeurs en Colombie-Britannique. Ce syndicat a souvent convenu avec des employeurs des accords collectifs en deçà des normes prévues par la législation sur les normes minimales de l'emploi, avant et à la suite des modifications de 2002. Dans bien des cas, ces accords ont conduit à une baisse des leur effectif les protections centrales de la loi Une différence majeure est à l'effet que, sous la loi existant entre 1995 et 2002 , salarié pouvait porter plainte par le biais d'un grief ou d'une plainte à la direction générale des normes de l'emploi et bénéficier de la protection de la loi, invalidant les normes inférieures à la loi contenues à la convention collective.

Les salariés couverts par des conventions collectives dont le CLAC était signataire ont perdu leurs accès légaux aux nombreuses dispositions concernant le salaire minimum et les avantages sociaux de la loi sur les normes minimales, en les plaçnt dans une relation d'emploi inférieure lorsqu'on les compare aux salariés qui ne sont pas représentés par un syndicat, voire même aux salariés représentés par un syndicat, mais qui avaient négocié l'une ou l'autre des dispositions concernant les heures de travail, le temps supplémentaire, les congés obligatoires, les vacances annuelles, etc. De plus, toute convention collective en vigueur au mois de mai 2002, qui contenait toute espèce de disposition, prévoyant des limitations ou des normes sous le seuil eu égard aux ections nouvelles de la loi traitant de l'exclusion, se retrouvait par ladoption du projet de loi confirmée dans un statur

Les entreprises se sont montrées favorables aux exclusions des accords collectifs en soutenant que cela aiderait les parties à letecie de prévoyaient aucune amélioration évidente en retour de concessions sous les normes faites par le syndicat.

Cet essai dén Cet essai démontre que la présomption à leffet que des échanges de bénefices nutuels se sont produits, là où les parties à une convention collective ont convenu de dispositions sous les normes, ne reçoit aucun appui. La preuve qui émerge de notre étude
supporte la conclusion à l'effet que l'introduction d'une législation, qui permet aux parties à une entente collective de négocier des dispositions minimales d'emploi, s'est traduite, dans le cas de plusieurs conventions collectives signées par le CLAC et analysées ici, par un déni injuste à l'endroit des travailleurs syndiqués en les privant des avantages et des droits que la législation voulait accorder à tous les travailleurs.

Cette étude reprend aussi les cas récents où des syndicats conventionnels ont connu une réduction du champ d'application de la loi sur les normes minimales pour de grandes sections de leurs membres. Sous la loi précédente, les syndicats savaient que, si leurs conventions collectives ne contenaient pas d'avantages et de droits au moins égaux à ceux prévus par la loi, les disposition de la loi prévalaient. Depuis 2002, ce n'est plus le cas et des groupes imposants de syndiqués ont possiblement perdu des droits d'emploi sans recours légal.
\end{abstract}

Tous droits réservés (C) Département des relations industrielles de l'Université Laval, 2009
Ce document est protégé par la loi sur le droit d'auteur. L'utilisation des services d'Érudit (y compris la reproduction) est assujettie à sa politique d'utilisation que vous pouvez consulter en ligne.

https://apropos.erudit.org/fr/usagers/politique-dutilisation/ 


\title{
Exclusion of Unionized Workers from Employment Standards Law
}

\author{
David B. Fairey
}

The technique of permitting unions to derogations from core employment standards has been increasingly advocated as a means of making labour law more flexible while still protecting workers since the union is considered to bring countervailing power in support of workers' preferences. The new British Columbia Employment Standards Act contains a broad union derogation provision. Industrial relations experts have commented that employment standards that permit the opting out of statutory employee protections in this way invites corrupt arrangements between employers and employer-dominated unions. Using the new BC statute as a case study, the assumption that requiring the union's consent to derogation from core standards ensures that the derogation reflects workers' preferences is tested using two sources of empirical data: collective agreements entered into by an employer friendly union (the Christian Labour Association of Canada); and collective agreements in which the union had neither the opportunity nor the strength to prevent derogation.

KEYWORDS: labour law, British Columbia, Bill 48, collective agreement, derogation provision

\section{Introduction}

Employment standards establish a floor of employee rights below which employers cannot go in establishing working conditions, and provide a starting point for negotiations for improved conditions when employees with a union negotiate a collective agreement (Arthurs, 2006: 74). They also establish a level playing field for employers, reducing unfair labour market competition.

Reviews of employment standards legislation in several provincial and federal jurisdictions over the past decade have attracted advocates for legislative change that would permit unions to consent to derogations from core standards. The technique of union derogation has been increasingly advocated as a means of making labour law more flexible while still protecting workers, since the union is considered to bring countervailing power in support of workers' preferences. The new British Columbia Employment Standards Act contains a broad union derogation provision. 
In May of 2002, the British Columbia government made a large number of changes to the Employment Standards Act, allegedly to make it more "flexible" and thus more beneficial to both employers and employees. One of the more significant changes made to the Act by passage of Bill 48 (Employment Standards Amendment Act, 2002, Ch. 42) was the exclusion from core provisions of the Act all employees covered by a collective agreement if their collective agreement contains "any language regarding those provisions" (Fairey, 2005: 17-19). This new feature of employment standards law is unique in Canada, although it has an earlier history in British Columbia (BC). It enables parties to a collective agreement to "opt out" of the law, and misleads unionized workers into thinking that they have all the rights that the Act provides, when in fact they may not, because their union failed to ensure that all provisions of the Act are minimally contained in their collective agreement.

This paper uses British Columbia's new statute as a case study to test whether the assumption that requiring the union's consent ensures that the derogation reflects the workers' preferences in circumstances where: (a) collective agreements were negotiated by an employer friendly union; and (b) unions in general had neither the opportunity nor the strength to prevent derogation in collective agreements negotiated.

\section{History of Collective Agreement Exclusion from Employment Standards Act}

It is very rare for government statutes to permit certain groups in society to remove themselves from ("opt out of") coverage of a law specifically designed to regulate the activities they are engaged in without prior government sanction or oversight. According to industrial relations experts, employment standards legislation that permits the "opting out" of basic employee protections by employers and their unions invites unwelcome levels of collaboration. Dr. Mark Thompson of the University of British Columbia, in comments on proposals to change the law in this way in BC, expressed the view that: "This policy is unwise because it opens the door for corrupt arrangements between employers and pseudo unions" (Thompson, 2001). Dave Ages, former manager of the Lower Mainland region of the BC Employment Standards Branch, expressed the view that this change in the law allows "... employers to collaborate with alternative, employer-dominated unions to undercut minimum standards" (Ages, 2002).

One of the controversial amendments made to the BC Employment Standards Act by the Social Credit government of Premier Bill Bennett in 1983 was the introduction of Section 2(2):

Where a collective agreement contains any provision respecting a matter set out in Column 1 of the following table, the Part of this Act set out opposite that matter in Column 2 does not apply in respect of employment pursuant to that collective agreement:

\begin{tabular}{lr} 
Column 1 Matter & Column 2 Part \\
\hline Hours of work or overtime & Part 3 \\
Annual vacation or vacation pay & Part 4 \\
Termination of employment or layoff & Part 5 \\
Maternity and parental leave & Part 7
\end{tabular}


At the time of introduction of Section 2(2) into the BC Employment Standards Act, no other jurisdiction in Canada had a comparable law to permit the parties to a collective agreement to "contract out of" minimum employment standards legislation in this way.

Immediately following the election of an NDP government in 1991, the new Minister of Labour, Moe Sihota, appointed a committee to review the Industrial Relations Act of the previous Social Credit government. During that review stakeholders were asked for their views on the linkages between the Industrial Relations Act and the Employment Standards Act, with specific reference to the collective agreement exclusion provision in Section 2(2). Representatives of employers submitted that Section 2(2) should be retained in the Employment Standards Act, while unions submitted that Section 2(2) should be repealed. Similar opposing views were submitted to the Employment Standards Review Commissioner in 1993.

According to Employment Standards Review Commissioner, Mark Thompson, the essence of the employers' argument in support of retention of Section 2(2) was that the parties in collective bargaining should have the right to fashion their own solutions to the issues covered by the Employment Standards Act, unencumbered by legal minima or the need to apply for variances. Employers acknowledged that some employers and unions consistently negotiated collective agreements containing provisions inferior to the Act. However, they argued that the number of such instances was small and should be dealt with in another way. Unions, on the other hand, argued that permitting collective agreement provisions below the standards of the Act placed other employers at a competitive disadvantage, and that exceptions to the Act should be dealt with through the 'variance' process, which had worked for many years prior to Section 2(2) (Thompson, 1993).

As a result of the new NDP government's commitment to repeal Section 2(2) in 1992, Employment Standards Review Commissioner Thompson's instructions were to prepare recommendations on an expedited basis for amendments to the Act that would enable the repeal.

In his Interim Report of June 2, 1993 Commissioner Thompson recommended the adoption of two principles to address the issue:

1. Collective agreements cannot exempt parties from the fundamental protections of the law, although the parties are free to agree to alternative arrangements that accomplish the same objective.

2. Statutory minimum standards must be respected in each section of the law, i.e. the parties are not free to trade off superior conditions in one section of the Act for inferior conditions elsewhere.

These principles Thompson adopted from Bill C-101 (1993), an act that had multi-party support in the federal parliament to amend Part III of the Canada Labour Code. Bill C-101 came out of an extensive process of consultation at the federal level by Labour Canada. The relevant new 1993 provision in the Code was (and still is) Section 168(1.1). 
In response to those who made the "flexibility" argument-that employers and unions should be free to trade off superior conditions in one section of the law for inferior conditions elsewhere-Thompson stated that while such a practice may be appealing in theory, it contradicts the principle that all citizens enjoy certain basic standards as a matter of right, not subject to negotiation (Thompson, 1993: 6).

Thompson did recommend that in conjunction with repeal of Section 2(2) of the BC Act, Part 3 (Hours of work and overtime), Part 4 (Annual Vacation pay), Part 5 (Termination or layoff), and regulations 4 and 5(a) (General Holidays) not apply to employees covered by a collective agreement where the collective agreement provides rights and benefits "at least as favourable" as those contained in the Act and the Regulation. This was consistent with Bill C-101 changes to the Canada Labour Code, and was a partial concession to employer pressure to retain the collective agreement "flexibility" provided in the 1983 BC Act. This was then translated into the "meet or exceed" exemption criteria provided in the Employment Standards Amendment Act, 1993 (Bill 65), which became effective January 1, 1994.

Commissioner Thompson clarified the intent of the "meet or exceed" conditional exemption of collective agreements with respect to the above four sections of the Act and the Regulation in the following statement:

The intent of this system is that the parties may negotiate arrangements concerning the subjects in each part, some elements of which may fall below the statutory minimum, but in their totality confer benefits at least as favourable as those required by the Act. Thus, the parties in collective bargaining may choose to forgo overtime pay after eight hours in exchange for greater leisure taken as part of work schedules, but not annual vacation (Thompson, 1993: 7).1

Significantly, Thompson recommended that this conditional exemption from core provisions of the Act not apply to Part 7 (Maternity and Parental Benefits), which the 1983 Section 2(2) blanket exemption had also applied to, with the reasoning that "a majority should not be permitted to impose its preferences on a minority in a matter as sensitive as maternity leave" (Thompson, 1993).

Thompson's recommended "meet or exceed" amendments to the Act were introduced in the legislature in July 1993 through Bill 65. Bill 65 also incorporated his recommendation that any disagreements as to whether collective agreement provisions conformed with the new requirements of the Act were to be resolved through grievance arbitration.

The Thompson Commission completed its full review of employment standards in British Columbia and submitted its second report to the Minister of Labour on February 3, 1994 (Thompson, 1994). Based on the Thompson report recommendations, the NDP government introduced a substantially rewritten Employment Standards Act in 1995 which incorporated the 1993 collective agreement "meet or exceed" exclusion amendments with respect to hours of work, overtime, special clothing, statutory holiday pay, annual vacation, and termination. The new wording in the Act with respect to hours of work, overtime and special clothing was as follows: 


\section{Standards for those covered by Collective Agreement}

1. If the hours of work, overtime or special clothing provisions of a collective agreement, when considered together, meet or exceed the requirements of this Part and section 25 when considered together, those provisions replace the requirements of this Part and section 25 [Special Clothing] for the employees covered by the collective agreement.

2. If the hours of work, overtime or special clothing provisions of a collective agreement, when considered together, do not meet or exceed the requirements of this Part and section 25 when considered together, (a) the requirements of this Part and section 25 are deemed to form part of the collective agreement and to replace those provisions, and (b) the grievance provisions of the collective agreement apply for resolving any dispute about the application or interpretation of those requirements.

Similar "meet or exceed" language also applied to the statutory holiday pay, annual vacation and termination provisions in the Act.

The issue of collective agreement exclusion from employment standards law next resurfaced in Ontario following election in 1995 of the Progressive Conservative government of Premier Mike Harris. On May 13, 1996, Ontario Labour Minister, Elizabeth Witmer, announced in the legislature that the government would be tabling legislation later in the year to amend the Employment Standards Actthe first installment in the Harris government's policy to introduce labour market "flexibility" (Fudge, 2001). Reminiscent of Section 2(2) in the 1983 BC Employment Standards Act, Ontario's Bill 49, the Act to Improve the Employment Standards Act, according to the press release accompanying it, represented "the first of a two-phase reform of the Act that will cut through years of accumulated red tape, encourage the workplace parties to be more self-reliant in resolving disputes and make the Act more relevant to the needs of today's workplace" (CCH Canadian, 1996; The Employment Standards Working Group, 1996).

However, the Ontario government subsequently withdrew those Bill 49 amendments that would have permitted unions and employers to negotiate their own employment standards after the Employment Standards Working Group-a broad coalition of legal clinics, unions, and advocates for workers' rightsmanaged to attract province-wide attention and opposition to the government's proposed amendments (Fudge, 2001). Ultimately, when the new Employment Standards Act, 2000 came into effect on September 4, 2001, employees covered by a collective agreement were provided with the following "no contracting out" and "meet or exceed" protections:

\section{No Contracting Out}

Sec. 5. (1) Subject to subsection (2), no employer or agent of an employer and no employee or agent of an employee shall contract out of or waive an employment standard and any such contracting out or waiver is void.

(2) If one or more provisions in an employment contract or in another Act that directly relate to the same subject matter as an employment standard provide a greater benefit to an employee than the employment standard, the provision or provisions in the contract or Act apply and the employment standard does not apply. (emphasis added). 
In BC the issue of collective agreement exclusion emerged again as an issue for 27 business organizations in 1997. A new Coalition of BC Business, formed in 1992 in response to the election of an NDP government to be an advocate and voice for small- and medium-sized businesses on labour and employment issues, made an 18-page submission to the Minister of Labour regarding the new Employment Standards Act. Among many recommendations for change "to provide employers and employees with the ability to tailor workplace flexible arrangements," the Business Coalition recommended that:

The variance procedure of the Act should be amended so that employers and employees can institute mutually agreeable working conditions that protect the employees from "bad" employers while providing the freedom to develop arrangements which are specifically tailored to the needs of the employees and the particular workplace (Coalition of BC Business, 1997).

The above recommendations, of course, went beyond workplaces covered by a collective agreement, and in essence would permit "contracting out" of the Act generally.

Over the next four years, the Coalition of BC Business and its closely allied Business Council of British Columbia (representing large- to medium-sized business) persisted in bringing pressure to bear on successive provincial governments to make radical changes to the Employment Standards Act and the Labour Relations Code. In an extensive policy document titled Labour Policies that Work: A New Vision for BC the Coalition of BC Business reiterated that while the government has a legitimate role in establishing basic standards for the workplace for the purpose of protecting employees, "[t]he establishment of such standards should not, however, preclude employees and employers from agreeing to variations on those standards to meet their mutual interests." It stated that the Employment Standards Act passed by the NDP in 1995 "represented a step backwards in respect of allowing for greater give-and-take between employers and employees in setting 'win-win' workplace rules." It argued that Section 2(2) of the 1983 Act had "offered considerable flexibility to unionized businesses and their employees but none to the non-union sector." And that "... a collective agreement should be basic evidence that the package of benefits is reasonable and agreed to by a majority of employees" (Coalition of BC Business, 2000).

In its December 2001 submission on employment standards to the new Liberal government of Premier Gordon Campbell, the Business Council of British Columbia also called for re-instatement of exclusion of employees covered by a collective agreement:

In workplaces where employees are represented by a trade union, the trade union and employer freely negotiate terms and conditions of employment that reflect the realities of those workplaces. The delicate series of trade-offs at which the parties invariably arrive in the course of negotiating an acceptable settlement should not be upset. Employment standards should not interfere with the daily operations of unionized work sites (Business Council of British Columbia 2001).

Beginning in November 2001, the new provincial government embarked upon a series of substantive changes to the Employment Standards Act, regulations under the Act, and the system of administration and enforcement of the Act. ${ }^{2}$ A superficial consultation process was launched by the Minister of Skills Development and Labour, on November 14, 2001, with release of a discussion paper titled Fair and Effective: A Review of Employment Standards in British Columbia. Interested individuals and groups 
were given just 28 days to provide written submissions in response, and there were no public hearings.

In Fair and Effective, one of the questions posed to interested parties was in relation to the 1995 Act's "meet or exceed" provisions for collective agreements: "Should workers with a collective agreement under the Labour Relations Code be covered by the Act?" the discussion paper asked. The options then identified were only those that had been advanced by business associations: (1) totally exclude from the Act those employees covered by a collective agreement; (2) exclude from the Act those employees covered by a collective agreement with some exceptions, e.g. pregnancy, parental leave, payment of wages, or other; or (3) where a collective agreement is silent on a provision in the Act, deem the Employment Standards Act to apply to workers under that collective agreement. Significantly, the Ministry's discussion paper noted that there was then (as now) no other Canadian jurisdiction with collective agreement exclusion provisions in employment standards law.

All BC employer organizations responding to the 2001 Fair and Effective discussion paper supported some form of exclusion of workers covered by a collective agreement, whereas all unions and workers advocacy groups opposed it.

In May 2002, following the short Ministry staff review of employment standards the previous winter, Bill 48, the Employment Standards Amendment Act, 2002, was introduced and passed in the BC legislature.

Under Bill 48, Section 3, Scope of the Act, subsection 2, language similar to the 1983 Section 2(2) was reintroduced. However, in comparison to the first collective agreement exclusion language of the 1983 Act, the collective agreement exclusion language in the new 2002 Act expands considerably on the scope of potential collective agreement exclusions. The only provision the 2002 Act did not copy from the 1983 Act was the permitted exclusion of Maternity and Parental Leave provisions.

Under the new Act, parties to a collective agreement can negotiate provisions with respect to hours of work and overtime, statutory holidays, annual vacations or vacation pay, termination of employment or layoff, paydays, termination pay, special clothing, payroll records, and several other significant issues, that are below the employment rights specified in the $A c t^{3}$. More significantly, the Act states broadly that if a collective agreement contains "any provision" with respect to the excludable basic rights listed, the workers covered by such a collective agreement no longer have access to those basic statutory rights.

In addition, workers and their unions no longer have access to the wage recovery mechanisms of the Act, or the protections and powers of enforcement of the Employment Standards Branch with respect to such serious issues as the employment of children, the payment of minimum wages, jury duty, and other statutory leaves, group terminations and termination notices. This dumping of enforcement of basic rights under the Act from the Employment Standards Branch (the government) to unions through collective agreement grievance procedures is unprecedented, denying as it does to all unionized employees the protections of government enforcement of the law. 


\section{The Incentive to Contract Out of Employment Standards in BC}

In BC's competitive labour relations environment, where employers tend to strenuously resist unionization, ${ }^{4}$ or try to minimize the cost impact of unionization, and where unions compete for employee representation rights, the opportunity to contract out of legislated employment standards provides employers with a strong incentive to lend support to weak, obliging or accommodating unions, and to apply pressure during collective bargaining to obtain such cost cutting concessions. When the Employment Standards Act did not permit contracting out of its provisions, it would have been an unfair labour practice for an employer to force a union to strike, or to lockout its workers, over employer demands for sub-standard collective agreement provisions.

To determine whether unions and employers have utilized the opportunities provided under the new Employment Standards Act to escape its core standards, and establish for their workers terms and conditions of employment that are inferior to the legislated minimums, requires identification of unions that are predisposed to acceding to employer pressures for such concessions, and to then examine the collective agreements they have entered into since the passage of Bill 48. Such concessions can occur because of the influence or dominance of employers in collective bargaining relationships, the absence of an adversarial relationship, the opportunities for unions to obtain voluntary recognition by employers, or the opportunities offered to unions to trade off legislated minimum standards for other gains for their members.

\section{Employer Influence on Unions: The Labour Relations Legal Framework}

Labour relations statutes across Canada typically define a union as an organization engaged in regulating employer-employee relations and requiring several essential elements, such as a constitution approved by members, and not being employer dominated or influenced (McNeil et al., 2005: 1-20). Under a number of provincial statutes, including the BC Labour Relations Code, both the definitions of "trade union" and sections dealing with the granting of bargaining agency certificates to unions specifically exclude organizations or associations of employees that are "dominated or influenced by an employer." The BC Labour Relations Code also prohibits an employer from interfering with the formation or administration of a trade union, or contributing financial or other support to it.

In the Canada Labour Code, Section 25: "... where the Board is satisfied that a trade union is so dominated or influenced by an employer that the fitness of the trade union to represent employees of the employer for the purpose of collective bargaining is impaired, the Board shall not certify the trade union as the bargaining agent ...". In the Ontario Labour Relations Act, Section 15, a trade union cannot be certified where the employer has participated in organizing, or to which the employer has contributed financial or other support (McNeil et al., 2005: 1-28.5). 
Under these legal standards, an applicant union, when challenged, must be able to demonstrate that it has the capacity to represent and conduct meaningful collective bargaining and advocacy on behalf of worker/employee interests, even if this requires an adversarial relationship with the employer.

However, a union does not have to prove its status in every proceeding before a labour relations board, once the board has found that an organization is a trade union pursuant to the definition in the statute (McNeil et al., 2005: 1-21). Consequently, a review of labour relations board decisions dealing with the certification of unions from across the country reveals that the same union can be found to be employer influenced or dominated and denied employee representation rights in the case of one employer, yet granted representation rights with another employer.

Once a union has been granted certification rights for a bargaining unit, the relationship between the union and the employer is never again put to the legal test of employer domination or influence unless an application is brought before a labour relations board for decertification, transfer of certification to another union, or failure to represent a member.

Under the BC Labour Relations Code, the labour relations board has determined that there are two situations when there is valid consideration of whether a union is employer dominated or influenced: (a) where the union is seeking certification for the first time in the province; and (b) where the union has an established history of collective bargaining in the province but has come under scrutiny because an interested party (e.g. another union) has raised the issue of employer dominance or influence. However, in the latter situation, the party raising the issue must have sufficient evidence to potentially prove the charge. ${ }^{5}$

In the case where an employer voluntarily agrees to enter into a collective agreement with a union without formal certification or challenge to the labour relations board, that relationship is also never put to the legal test of employer domination or influence unless subsequently, representation applications by members or other unions are brought before the labour relations board. Therefore, whether in fact a union is employer dominated or influenced is not independently determined in every case, and only occurs in exceptional cases where there is a challenge based on such a claim before a labour relations board.

\section{Collective Agreements Considered for Analysis}

The Canadian Iron, Steel and Industrial Workers Union (CISIWU) was a potential subject for investigation for the purpose of this research project because of its reputation as an "alternative" outlier union. ${ }^{6}$ But its small size, and the difficulty of obtaining a good sample of recently negotiated collective agreements, made it a poor subject for research. However, it is important to note that CISIWU was the subject of a similar investigation by the Fair Wage Compliance Team of the BC Employment Standards Branch in 1999.

Responding to complaints by construction companies in competition with companies under CISIWU collective agreements, which they claimed did not meet the minimum standards of the Act, the Director of Employment Standards ordered an 
analysis of CISIWU collective agreements to determine if they met or exceeded the Act with regard to Parts 4, 5, 7 and 8. The Fair Wage Compliance Team provided the Director with the results of that analysis in a report titled Analysis of the Canadian Iron, Steel and Industrial Workers Union, Local 1 - Various Collective Agreements and the Employment Standards Act, Sections 43, 49 and 61. In that report the Director was advised that several of the CISIWU collective agreements did not meet or exceed the Act, and that these substandard agreements were having a direct impact on the ability of other union and non-union employers to compete with these companies. As a consequence, the Director took corrective action and ordered the Rand Reinforcing Ltd./CISIWU collective agreement to contain the minimum standards of the Act, replacing those sections found to not meet the requirements of the Act. $^{7}$

Another small "alternative" outlier union in BC has been the General Workers Union (GWU). In 2000 the GWU merged with the Christian Labour Association of Canada (CLAC). At the time of merger, it was estimated that GWU had agreements with between 42 and 77 employers covering up to 2,000 workers.

CLAC is the largest and most important of the alternative outlier unions identified for examination, with a national membership of approximately 40,000 in 2006 (de Zoete, 2006) and, according to staff at CLAC's Surrey, BC office, a membership of approximately 11,600 in British Columbia.

\section{Why CLAC Collective Agreements Were Chosen for Analysis}

The Christian Labour Association of Canada was selected for this study as an employee organization susceptible to undue employer influence or willingness to be accommodating in the negotiation of collective agreements for a number of reasons, its significant size being one.

As early as 1978, labour relations literature has characterized CLAC as "a trade union that has some unusual ideas about the manner in which labour relations should be conducted." (Pellettier, 1978: 264). CLAC's constitution, principles, practices and publications clearly distinguish it from traditional Canadian unions (Christian Labour Association of Canada, 2004).

According to former CLAC Executive Director Ed Grootenboer, author of a recently published history of the union: "As a labour union inspired by Christian principles, CLAC is unique in present-day Canada, ... the establishment and operation of CLAC stand in stark contrast with similar organizations, which base themselves on different world and life views." (Grootenboer, 2005: ix). Grootenboer goes on to state that: "CLAC is not an ordinary trade union, given its overt adherence to the Christian world and life view and its consequent aversion to some key practices widely accepted as standard by the trade union establishment" (Grootenboer, 2005: 45).

In Ontario, CLAC was refused the right to be certified as a union to represent groups of employees (on grounds that it discriminated on the basis of creed) until 1963, when the Supreme Court of Ontario overturned a Labour Relations Board decision denying it certification rights to represent construction workers employed by Tange Company 
Limited (Pellettier, 1978: 265; Grootenboer, 2005: 31-42). Grootenboer portrays CLAC's first eleven years of struggle for representational rights in competition with traditional unions as one founded on "a clash of world views: Christian versus Marxist/ socialist, or a purely secular world view" (Grootenboer, 2005: 12).

With the possible exception of Ontario, wherever CLAC has established a significant presence, it has been based primarily on representation of workers in the construction industry. In contrast to the traditional "skilled trades" basis of union representation in construction (i.e. carpenters represented by the Carpenters' Union, plumbers represented by the Plumbers' Union), CLAC offers to represent all construction workers employed by each company, regardless of trade, in so-called "all employee" bargaining units. In addition, CLAC does not require that all employees in the bargaining unit be union members in so-called "closed shops," or dispatched to construction projects through a union "hiring hall," as traditional construction unions do. In offering employers "all employee" bargaining units, "open shops," and direct employee hiring, CLAC has made itself the preferred union of many large construction companies who have offered it voluntary recognition agreements and employer-wide or province-wide employee representation. ${ }^{8}$

Currently, CLAC is unable to obtain certification rights to represent construction workers in Nova Scotia as a result of a Labour Relations Board decision in 2000 which found that CLAC did not constitute a 'trade' union in the construction industry as defined by the Act. ${ }^{9} \mathrm{~A}$ similar legislative bar to certification for construction workers also exists in Saskatchewan. ${ }^{10}$ Consequently, CLAC has little or no presence in either province, and no presence in Quebec or Newfoundland and Labrador. CLAC's membership is therefore concentrated in Ontario, Alberta and British Columbia (2005 membership: 10,553; 15,295; and 11,608 respectively); it also has about 590 members and an office in Manitoba, and in recent years has been very active in seeking to represent miners in the Northwest Territories. ${ }^{11}$

According to former CLAC leader Grootenboer: "A practice flowing from the union's Christian basis is the striving for cooperative, as opposed to adversarial, relations with employers." (Grootenboer, 2005: 17). A consequence of this practice is that CLAC never undertakes strike action ${ }^{12}$ to obtain a collective agreement without first offering employers the avenues of mediation and voluntary binding arbitration (Grootenboer, 2005: 119). Consistent with this non-adversarial approach to labour relations, CLAC advocates that the provincial and federal governments abolish strikes and lockouts and impose mandatory arbitration instead to resolve collective agreement disputes (Grootenboer, 2005: 116).

In its first 26 years of existence, CLAC did not conduct any strike activity. Over the next 24 years, CLAC conducted only three strikes. In his $50^{\text {th }}$ anniversary history of CLAC, Ed Grootenboer was able to observe that CLAC strikes "have been few and far between" (Livesay, 1998: 28; Grootenboer, 2005: 118).

CLAC continues to promote itself as spearheading an alternative labour movement that practices cooperation with employers on the basis of social justice and love as taught in the Bible, and which opposes class conflict in seeking the removal of injustice. ${ }^{13}$ 
While no labour tribunal has found that CLAC generally and in all instances is employer dominated or influenced, or seeks to accommodate or practice collusion with employers, it is observed that this organization does not appear to see the necessity of maintaining an arm's-length relationship with employers. This observation is drawn from an extensive review of a large number of documents, reports, collective agreements and labour relations board decisions involving CLAC. ${ }^{14}$

In short, CLAC has the appearance of a union that many employers would prefer to deal with because it promotes itself as a "flexible" organization that is attentive to employer interests.

\section{CLAC Collective Agreements Analysis}

The selection of CLAC collective agreements for analysis was essentially random. After assembling as many relatively current collective agreements as possible as were available from a variety of cooperatives sources, such as the BC Labour Relations Board web site, the Trade Union Research Bureau Library, the BC Federation of Labour library, and a number of trade unions, these were screened to retain for analysis all the agreements negotiated after Bill 48 (May 2002), plus the agreements for the same bargaining units that preceded the post Bill 48 agreements.

Our review of CLAC collective agreements negotiated both before and after passage of the Bill 48 amendments to the Employment Standards Act in May 2002 covered CLAC's relationship with a total of $37 \mathrm{BC}$ employers in the following sectors.

\section{TABLE 1}

CLAC Collective Agreements Analyzed by Sector

Sector

NEGOTIATION DATE

CONSTRUCTION

TRANSPORT

MANUFACTURING

MINING

HEALTH

TOTAL

PRE BILL 48

10

17

6

27

12

4

3

13

SECTOR TOTAL

$21.4 \%$

$12.5 \%$

$5.4 \% \quad 12.5 \%$

$100 \%$

Of the 56 collective agreements analyzed covering 37 separate bargaining units, 24 were negotiated before passage of Bill 48 , and 32 were negotiated after passage of Bill 48. Also, of the total 56 agreements analyzed, 38 were for 19 bargaining units where two agreements were reviewed: one negotiated in the period immediately prior to Bill 48, and one negotiated after Bill 48.

Given that CLAC represents a total of approximately 313 bargaining units in BC, the 37 bargaining units for which collective agreements were analyzed constitute a significant sample of approximately $12 \%$ of all CLAC bargaining units in BC. In addition, this sample is fairly representative of CLAC's presence in each of the five sectors covered above (see Table 1). 
Of the 24 CLAC agreements analyzed that were negotiated prior to Bill 48, 23 were found to contain at least one sub-standard condition relative to core provisions of the Employment Standards Act in effect from 1994 to 2001. Out of a total of about 12 kinds of sub-standard provisions found, the most common deficiency found in the pre Bill 48 CLAC agreements related to entitlement to Statutory Holidays (where, in one case, casual workers were completely excluded), entitlement to annual vacation with pay, premium or overtime pay and/or a day off in lieu of work on a Statutory Holiday, other overtime pay, and provision for a meal break after five hours of work. In most instances, the collective agreements contained more than one substandard provision and as many as eight substandard provisions. ${ }^{15}$

These findings demonstrate that prior to the collective agreement exclusion provisions of the new Act under Bill 48, CLAC regularly negotiated collective agreements that did not meet all the minimum standards of the Employment Standards Act. However, under the 1994 - 2002 Act, an employee working under a sub-standard agreement would have, through the filing of a grievance or a complaint to the Employment Standards Branch or Labour Relations Board, been entitled to the minimum protections of the Act.

Of the 32 CLAC agreements analyzed that were negotiated after passage of Bill 48,28 were found to contain at least one sub-standard condition relative to the core provisions of the new Act (which itself provides inferior protections compared to the old Act). The most common deficiency found in the post Bill 48 agreements related to annual vacations with pay (20 cases), overtime pay (9), meals breaks (7), notice of termination or severance pay in lieu of notice (7), entitlement to Statutory Holidays and/or pay for work on a Statutory Holiday (5), and maximum hours of work (5).

In a small number of these agreements, overtime rates of pay were actually reduced from their pre Bill 48 provisions. In one alarming case (JJM Construction Ltd. and CLAC Local 67, May 9, 2003 Letter of Understanding), employees' regular rates of pay were reduced by $20 \%$ for work in excess of eight hours per day or 40 hours per week, on Saturdays, Sundays, and Statutory Holidays, before overtime rates apply. These provisions are clearly at variance with the overtime requirements of the Act, were it not for the new Section 3(2) collective agreement exclusion exceptions, and in addition, at variance with labour relations law. The Employment Standards Act provisions relating to overtime wages and statutory holidays require that the premium pay to be paid (time and one half or double time) be based on employees' regular rates of pay. This JJM agreement violates the Act as the effective overtime rates of pay are $20 \%$ less than they would be under the minimum standards of the Act.

In another notable collective agreement (Northwest Waste Systems Inc. and CLAC Local 66), probationary employees (those with 1,000 hours or less of employment) were excluded from most of the collective agreement provisions reserved for regular employees, and provided with pay and benefits significantly below the Act.

The latter two cases clearly demonstrate that the new collective agreement exclusion provisions of Bill 48 have enabled employers to obtain from cooperative and obliging unions such as CLAC collective agreement provisions significantly below those mandated for all employees under the Act. 
In 13 of the post Bill 48 CLAC agreements analyzed, the excludable Parts 3, 4, 5,7 and 8 of the new Act have been newly written into the collective agreement with the following wording: "The parties agree that Parts 3, 4, 5, 7 and 8 of the Employment Standards Act form part of this collective agreement, except those provisions specifically modified by this collective agreement." 16

This direct reference to the new excludable parts of the Act creates confusion and uncertainty, especially where the collective agreement also contains vague or limited language on any of the conditions covered by those parts of the Act. For example, it is unclear as to whether a collective agreement with no termination with pay provision but with some language respecting layoff notice would be deemed to contain all or none of Part 8 of the Act (Termination of Employment). Or in the case of a collective agreement that contains no overtime pay provision except for employees who work on afternoon shift (who might only get pay at time and one half after 10 hours worked per day), it is unclear if all employees would be covered under Part 4 of the Act (Hours of Work or Overtime), or if those on other shifts would be excluded from Part 4. There is potential for loss of employee protection from the excludable parts of Act in all such cases because their collective agreements contain "any provision respecting a matter" within the relevant part of the Act.

As a result of Bill 48, employees covered by the above referenced CLAC collective agreements have lost their legal rights to several of the minimum wage and benefit provisions of the Employment Standards Act, placing them in inferior employment relationships compared to employees not represented by a union, or even employees represented by a union which has not negotiated any provision respecting hours of work and overtime, statutory holidays, annual vacations or vacation pay, seniority retention, recall, termination of employment, or layoff, etc.

In the lead up to Bill 48, business organizations argued in support of these collective agreement exclusions on the basis that they would enable parties to collective bargaining to reach mutually beneficial trade-offs, in other words, employers would be willing to give improved conditions in one part of an agreement if unions would agree to sign away their members' statutory rights in other parts, where the Act permitted such concessions. While an examination of collective agreement provisions resulting from such trade-off bargaining alone would not normally reveal whether or how such deliberate trade-offs were actually made (trade-offs are not recorded in such agreements), the CLAC collective agreements analyzed in this study did not indicate any obvious improvements in return for the substandard concessions made by the union. ${ }^{17}$

\section{Legislated Exclusion of Unionized Workers has Broad General Impacts}

The collective agreement exclusion provisions of the May 2002 Employment Standards Act also exposed unionized workers, in general, to the possible loss of workplace rights, due to the fact that in the previous eight and one half years all collective agreements were deemed to contain rights and benefits at least equal to those in the Act, regardless of the scope and content of their collective agreement language. The 
"meet or exceed" provisions of the Employment Standards Act in effect before the Bill 48 amendments were in effect from 1994 to 2001. Under that statute, unions were aware that if their collective agreements did not contain rights and benefits at least equal to the Act, the provisions of the Act were deemed to form part of their collective agreement. Consequently, unions had no need to pay particular attention to their collective agreement language in relation to rights and benefits covered in the Act, unless they were negotiating a completely new agreement or adding special or superior benefits to a previously negotiated agreement. Even if their agreement only addressed the special application of a right or benefit under the Act to a particular sub-group of employees within a larger bargaining unit, the rest of the bargaining unit was deemed entitled to the rights and benefits of the Act.

Bill 48's new collective agreement exclusion provisions turned the previous status of collective agreement language on its head, and no transitional provision was made to permit a period of adjustment or relief so that those agreements in effect could be changed to reflect the previous intent of parties that the employees covered retained their basic rights under the Act. Any collective agreement in effect as of May 2002 that contained "any provision" whatsoever, no matter how limited or substandard with respect to the new excludable parts of the Act was, by Bill 48, legislated into an exclusion status without recourse.

In addition, any collective bargaining to renew an agreement after May 2002, that did not consider the reversed status of previously negotiated collective agreement language in relation to the new excludable areas of the Act, could result in what might be termed an "inadvertent loss" of rights for workers covered by such an agreement.

This "inadvertent loss" of Employment Standards Act rights for employees under collective agreements was harshly revealed in a number of collective agreement grievance arbitration decisions issued since May 2002. In an April 2004 decision, arbitrator David McPhillips denied a grievance brought by National Automobile, Aerospace, Transportation and General Workers of Canada (CAW), Local 3000, against Securitas Canada Ltd. that it was in breach of the collective agreement and the Employment Standards Act Part 4 (Hours of Work or Overtime) in not paying overtime payments to employees working 12-hour shifts when they worked in excess of 40 hours in any week. The arbitrator ruled that because the collective agreement contained provisions regarding hours of work and overtime, the Employment Standards Act did not apply, even though the collective agreement also made reference to complying with provisions of the $A c t$, because the parties were "... free to arrive at a bargain which does not accord with the provisions of Part 4 of the Act" (B.C.C.A.A.A. No. 80, Award No. A-050/04, p.14).

In a 2005 decision, arbitrator Rick Coleman similarly denied a grievance by Retail Wholesale Union, Local 580, against Choice Warehouse and Distribution that the employer had violated Section 63, Part 8, of the Employment Standards Act respecting severance pay in lieu of termination notice. The arbitrator ruled that Section 63 had no bearing on the issue because the collective agreement contained its own language on the issue, and this language stood on its own (B.C.C.A.A.A. No. 127, Award No. X-015/05). 
In an October 2005 decision, arbitrator R. K. McDonald denied a grievance by United Steelworkers of America, Local 1-424, against Canadian Woodworks Ltd. for not providing a laid off employee 8 weeks' wages in lieu of notice of termination pursuant to Section 63, Part 8, of the Employment Standards Act. The arbitrator ruled that the individual employee was not entitled to the severance pay provisions of the Act because the collective agreement contained a clause that stated that only in the event of a permanent plant closure would the severance pay provisions of the Act apply. The collective agreement was silent with respect to severance pay in the event of layoff without plant closure. The arbitrator found that because the collective agreement contained specific language for the payment of severance, limited as it was to permanent plant closure, the new collective agreement exclusions provisions of the Act automatically excludes all employees under that collective agreement from the Act's minimum seniority retention, recall, termination of employment or layoff in any other circumstance (B.C.C.A.A.A. No. 236, Award No. A-165/05). This decision was appealed to the BC Labour Relations Board. After reviewing the arbitrator's decision, in this case the BCLRB agreed with the arbitrator's interpretation of the collective agreement and the Employment Standards Act. ${ }^{18}$

\section{Conclusion}

Although Federal Labour Standards Review Commissioner Arthurs declined to change or expand upon the very limited and restrictive collective agreement exclusion provisions of Part III of the Canada Labour Code, in considering the issue he noted that there were numerous collective agreements on file with the federal Labour Program which had surrendered various protections provided by the statute, implying that some form of opting out of Part III had occurred. Professor Arthurs then presumed (without supporting evidence) that the unions party to such collective agreements have voluntarily surrendered statutory protections "... in return for concessions offered by employers and desired by their member" (Arthurs 2006: 74).

In this article we have demonstrated that a general presumption that mutually beneficial trade-offs have taken place where parties to a collective agreement have agreed to provisions substandard to the statute is not supportable. The evidence from our research into collective agreements recently concluded in British Columbia supports a conclusion that the introduction of legislation that permits parties to a collective agreement to contract out of employment standards protections is just as likely to invite questionable arrangements between employers and their overly accommodating unions, and unjustly deny unionized workers the minimum rights and benefits the statute was designed to provide to all workers.

In a research report prepared for the Federal Labour Standards Review Commission on the subject of labour standards enforcement, Professor Paul Gallina considered the question of whether labour standards statutory minimums should apply to unionized work places. His conclusion was that "there is good legal precedent to support that one cannot bargain away one's statutory rights in a collective agreement," and that this principle should be upheld (Gallina, 2006: 46). 
By reintroducing and expanding upon collective agreement exclusion provisions in the Employment Standards Act through Bill 48, the BC government in 2002 cast aside a fundamental principle established for employment standards law by the government of Canada in 1993 ${ }^{19}$ - a principle endorsed by BC's only independent employment standards review commissioner, Professor Mark Thompson, and by every other legislature in Canada-and turned back the clock on equal rights under the law for employees represented by a union.

This research has revealed that the Christian Labour Association of Canada-the largest employer accommodating union in $\mathrm{BC}$-relative to the collective agreements reviewed, commonly conceded to employers substandard provisions relative to core parts of the Employment Standards Act prior to the passage of Bill 48, and has continued this practice after Bill 48, which in many instances has resulted in a lowering of wages and working conditions below the new lower minimum protections of the Act, and/or denying sections of their membership the core protections of the Act.

This research has also revealed how, in real life cases, traditional unions that have consistently pursued adversarial relationships with employers have been victim to the loss of Employment Standards Act coverage for large sections of their members, through legislative decree, in light of changes to the Act brought about by the new exclusion provisions in Bill 48. As a result, large groups of union members have potentially lost employment rights without legal recourse.

\section{Notes}

1 Two boards of arbitration under the Labour Relations Code subsequently interpreted more clearly the intent of the "meet or exceed" provisions of the Employment Standards Act, and established a method by which collective agreement provisions should be compared to the minimum provisions of the Act: Crestbrook Forest Industries and IWA-Canada, Local 1-405 (B.C.A.A.A. No. 127, Award No. A-121/95, April 1995); and Vancouver Island Haven Society and Health Sciences Association of BC (BCLRB No. B359/97, July 1997).

2 The first change to employment standards instituted by the new Liberal government actually occurred in July 2001 when, by British Columbia Regulation 177, variances and exclusions for oil and gas field first aid attendants and camp catering workers were approved by Order in Council.

3 An example of a negotiated provision which is contrary to the Act is reviewed later in the paper. It involves the overtime provision in a JJM Construction Ltd. collective agreement where the regular rate of pay is reduced by $20 \%$ when overtime is payable.

4 In Labour Left Out Professor Roy Adams cites a number of authoritative sources to establish the fact that in Canada generally "... employer opposition to unionization is widespread" (Adams, 2006: 18-25).

5 See Speed-Erect Foundations and Framing Systems Ltd. \& Local \#1 CISIWU \& United Brotherhood of Carpenters, et al. (BCLRB No. B1/93, January 18, 1993).

6 CISIWU has never been affiliated with the Canadian Labour Congress, the provincial federations of labour, or the provincial councils of building trades unions. It is frequently in competition with the latter, offering employers a more collaborative relationship.

7 Rand Reinforcing successfully appealed the Director's determination in this case to the Employment Standards Tribunal, where the Tribunal found that the Director had not the 
authority to decide whether the provisions of the collective agreement meet or exceed the statutory minimums in the relevant corresponding Part of the Act (see BC EST \#d123/01).

8 Evidence of employer preference for CLAC over other unions is found in the "recruitment" page of the internet website of the Progressive Contractors Association of Canada where CLAC is the only construction union link provided.

9 Reported at 65 C.L.R.B.R. (2nd) 1.

10 The Construction Industry Labour Relations Act. Chapter C-29.11, Statutes of Saskatchewan, 1992.

112005 membership statistics provided by staff at CLAC's Surrey office in May 2006.

12 No strike is allowed to be taken by a CLAC bargaining unit or Local without authorization from the CLAC National Board (CLAC Constitution, 2004, Article 9.14; Grootenboer, 2005: 119), and any member who promotes, organizes or participates in any unauthorized job action is subject to suspension and/or expulsion from membership in CLAC (CLAC Constitution, 2004, Article 6.04(f)).

13 See CLAC Constitution, 2004, Supplement B: 49. It is also to be noted that one of the primary principles CLAC is committed to promoting is "The interdependence of employers and employees, their many common interests, their obligations and responsibilities toward each other, ... and given fulfillment in obedience of the law of love demand that there be cooperation between them ...". (emphasis added) (CLAC Constitution, Supplement A: 47).

14 In order to keep this article within the length guideline of this journal, the author has had to leave out a listing of documents, actions and authorities that lend support to this observation. These references are available on request from the author.

15 This examination of collective agreements provisions to determine conformance with the minimum provisions of the Act is not without precedent. As previously noted, in 1999 the Employment Standards Branch, in response to complaints from construction companies that CISIWU and a number of employers were signing sub-standard agreements, and thereby engaging in unfair competition, conducted such a study and found the allegations to be true.

16 From CLAC Local 66 collective agreement with Northwest Waste Systems Inc., signed May 20, 2004.

17 The reference here is to the analysis of CLAC collective agreements negotiated with the same employer both immediately prior to and following Bill 48.

18 See BCLRB No. B26/2006.

19 Bill C-101 (collective agreements cannot exempt parties from the protections of the law), see above.

\section{References}

Adams, Roy J. 2006. Labour Left Out: Canada's Failure to Promote Collective Bargaining as a Human Right. Ottawa: Canadian Centre for Policy Alternatives.

Ages, Dave. 2002. "An Analysis of the Employment Standards Amendment Act, 2002." Creative Resistance, 2002-06-02. (This web-based publication is no longer accessible, but a copy of the article is available from the author.)

Arthurs, Harry W. 2006. Fairness at Work: Federal Labour Standards for the $21^{\text {st }}$ Century. Ottawa: Human Resources and Skills Development Canada.

British Columbia. 2001. 2001 Fair and Effective: A Review of Employment Standards in British Columbia. Victoria: Queen's Printer.

Business Council of British Columbia. 2001. Submission of Business Council of British Columbia on Employment Standards. Vancouver, December. 
CCH Canadian. 1996. "Employment Standards Act Window: Opened or Closed?" Canadian Industrial Relations \& Personnel Developments. Toronto, July.

Christian Labour Association of Canada. 2004. Constitution, adopted at National Convention. October 29.

Coalition of BC Business. 1997. BC's Employment Standards Act, A Submission to the Minister of Labour. Vancouver, December.

Coalition of BC Business. 2000. Labour Polices That Work: A New Vision for the New World of Work. Available at: <http://www.bcrfa.com/pdfs/labour_paper.pdf>.

de Zoete, Dolf. 2006. "One Challenge at a Time." The Guide, 54 (2). Mississauga: Christian Labour Association of Canada.

Fairey, David. 2005. Eroding Worker Protections: British Columbia's New 'Flexible' Employment Standards. Vancouver: Canadian Centre for Policy Alternatives - BC Office, November.

Fudge, Judy. 1996. "The Real Story: An Analysis of the Impact of Bill 49, the Employment Standards Improvement Act, upon Unorganized Workers." July (unpublished).

Fudge, Judy. 2001. "Flexibility and Feminization: The New Ontario Employment Standards Act." Journal of Law and Social Policy, Vol. 16.

Gallina, Paul. 2006. New Compliance Strategies: 'Hard law' Approach. A Report prepared for the Federal Labour Standards Review. Ottawa: Human Resources and Skills Development Canada.

Grootenboer, Ed. 2005. In Pursuit of Justice, So Far, So Good. Mississauga: Christian Labour Association of Canada.

Livesay, Bruce. 1998. "Who are our Brothers? The Christian Labour Association of Canada." Our Times, September/October, 27-32.

McNeil, Michael, Michael Lynk and Peter Engelman. 2005. Trade Union Law in Canada. Aurora, Ont.: Canada Law Book.

Pellettier, Paul. 1978. "Union Security and the Religious Objector: Section 39 of the Labour Relations Act." 4 Queen's Law Journal, 256-288.

The Employment Standards Working Group. 1996. The Real Story: An Analysis of the Impact of Bill 49, the Employment Standards Improvement Act, upon Unorganized Workers. Toronto, July.

Thompson, Mark. 1993. Review of Employment Standards Act: Interim Report. British Columbia Ministry of Labour and Consumer Affairs, June 2.

Thompson, Mark. 1994. Rights and Responsibilities in a Changing Workplace: A Review of Employment Standards in British Columbia, Report for the B.C. Ministry of Skills, Training and Labour.

Thompson, Mark. 2001. "Unpublished Letter to Ms. Betty Notar, Assistant Deputy Minister, Ministry of Skills Development and Labour, Re: Review of Employment Standards." December 11.

Waldie, Paul, Patrick Brethour and Susan Bourette. 1996. "Ontario Seen Headed for Labour Turmoil." The Globe and Mail, May 15. 


\section{RÉSUMÉ}

\section{L'exclusion des travailleurs syndiqués de la législation sur les normes minimales d'emploi}

La législation sur les normes minimales d'emploi présente un seuil de protection pour les employés en deçà duquel les employeurs ne peuvent fixer les conditions de travail. Elle constitue ainsi un point de départ pour la négociation de conditions de travail, lorsque les salariés représentés par un syndicat négocient une convention collective (Arthurs, 2006 : 74). La loi permet également de limiter les pratiques déloyales de concurrence sur les conditions de travail.

En mai 2002, le gouvernement de la Colombie-Britannique, au Canada, a effectué un nombre important de modifications à sa législation sur les normes minimales de l'emploi, en prétendant lui donner plus de flexibilité et, par conséquent, la rendre plus avantageuse pour les salariés et les employeurs. Une des modifications les plus importantes apportée à cette loi consistait à exclure de ses dispositions principales tous les salariés couverts par des conventions collectives, si ces dernières contenaient quelque allusion à ces dispositions.

Les travailleurs syndiqués de la Colombie-Britannique avaient déjà été exclus des protections principales prévues à la loi sur les normes au cours de l'année 1983. Suite à une révision, au début des années 90 , cette disposition a été infirmée au motif que les conventions collectives ne pouvaient exclure les parties de la protection fondamentale de la loi. Cependant, on a convenu qu'un certain degré de flexibilité serait introduit en autant que les conventions collectives dans leur ensemble rencontreraient ou excéderaient les normes minimales de l'emploi.

Les modifications apportées en 2002 à la loi ont rétabli les dispositions d'exclusion de 1983, dans des termes plus vastes et généraux. En ce faisant, elles ont encouragé les parties à s'exclure de la loi et elles ont induit en erreur les travailleurs syndiqués qui pensent qu'ils bénéficient de tous les droits prévus à la loi, alors qu'en fait, ce n'est pas toujours le cas.

Une des conséquences de ces modifications de 2002 est à l'effet de permettre à des unions collaboratrices ou en collusion avec des employeurs de négocier ouvertement des ententes se situant en deçà des normes de protection prévues par la loi. La législation en matière de relations du travail à l'échelle canadienne reconnaît d'une manière particulière un syndicat comme une organisation impliquée dans la régulation des rapports du travail, et qui doit, entre autres éléments essentiels, être dotée d'une constitution adoptée par ses membres et ne pas être dominée par un employeur ou sous l'influence de ce dernier. La Colombie-Britannique a historiquement abritée un petit nombre de syndicats " alternatifs " délaissant la confrontation, qui sont apparus sur la scène quand les employeurs opposaient une résistance aux efforts de syndicalisation des syndicats. Ces syndicats ont signé des ententes de reconnaissance volontaire avec les employeurs qui se situaient en deçà des normes de l'industrie.

Cet essai effectue une révision des conventions collectives signées par l'Association chrétienne du travail du Canada (CLAC), le syndicat alternatif le plus important au plan de l'accommodement avec les employeurs en Colombie-Britannique. Ce syndicat a souvent convenu avec des employeurs des accords collectifs en deçà des normes prévues par la législation sur les normes minimales de l'emploi, avant et à la suite des modifications de 
2002. Dans bien des cas, ces accords ont conduit à une baisse des salaires et des conditions de travail en deçà des protections minimales prévues par la loi, ou bien en refusant à des sections de leur effectif les protections centrales de la loi. Une différence majeure est à l'effet que, sous la loi existant entre 1995 et 2002, un salarié pouvait porter plainte par le biais d'un grief ou d'une plainte à la direction générale des normes de l'emploi et bénéficier de la protection de la loi, invalidant les normes inférieures à la loi contenues à la convention collective.

Les salariés couverts par des conventions collectives dont le CLAC était signataire ont perdu leurs accès légaux aux nombreuses dispositions concernant le salaire minimum et les avantages sociaux de la loi sur les normes minimales, en les plaçant dans une relation d'emploi inférieure lorsqu'on les compare aux salariés qui ne sont pas représentés par un syndicat, voire même aux salariés représentés par un syndicat, mais qui avaient négocié l'une ou l'autre des dispositions concernant les heures de travail, le temps supplémentaire, les congés obligatoires, les vacances annuelles, etc. De plus, toute convention collective en vigueur au mois de mai 2002, qui contenait toute espèce de disposition, prévoyant des limitations ou des normes sous le seuil eu égard aux sections nouvelles de la loi traitant de l'exclusion, se retrouvait par l'adoption du projet de loi confirmée dans un statut d'exclusion sans recours prévu.

Les entreprises se sont montrées favorables aux exclusions des accords collectifs en soutenant que cela aiderait les parties à négocier de meilleures conditions dans une section de la convention, si les syndicats acceptaient d'écarter les droits prévus à la loi dans d'autres sections, dans les situations permises par la loi. Les conventions collectives que nous avons étudiées ne prévoyaient aucune amélioration évidente en retour de concessions sous les normes faites par le syndicat.

Cet essai démontre que la présomption à l'effet que des échanges de bénéfices mutuels se sont produits, là où les parties à une convention collective ont convenu de dispositions sous les normes, ne reçoit aucun appui. La preuve qui émerge de notre étude supporte la conclusion à l'effet que l'introduction d'une législation, qui permet aux parties à une entente collective de négocier des dispositions minimales d'emploi, s'est traduite, dans le cas de plusieurs conventions collectives signées par le CLAC et analysées ici, par un déni injuste à l'endroit des travailleurs syndiqués en les privant des avantages et des droits que la législation voulait accorder à tous les travailleurs.

Cette étude reprend aussi les cas récents où des syndicats conventionnels ont connu une réduction du champ d'application de la loi sur les normes minimales pour de grandes sections de leurs membres. Sous la loi précédente, les syndicats savaient que, si leurs conventions collectives ne contenaient pas d'avantages et de droits au moins égaux à ceux prévus par la loi, les dispositions de la loi prévalaient. Depuis 2002, ce n'est plus le cas et des groupes imposants de syndiqués ont possiblement perdu des droits d'emploi sans recours légal.

MOTS-CLÉS : droit du travail, Colombie-Britannique, Bill 48, convention collective, clause dérogatoire 


\section{RESUMEN}

\section{La exclusión de trabajadores sindicalizados de la normas legales del empleo}

La técnica que permite a los sindicatos de hacer derogaciones de las normas esenciales de empleo se ha acrecentado defendiéndose como medio de obtener una mayor flexibilidad de la ley laboral e incluso un medio para proteger los trabajadores pues se supone que el sindicato es brinda la contrabalanza del poder en apoyo a las preferencias de los trabajadores. La nueva Acta de normas del empleo de la Colombia Británica incluye una amplia potestad sindical de derogación. Los expertos de relaciones industriales han comentado que las normas de empleo que han permitido la opción de renunciar de esta manera a las protecciones estatutarias del empleado, fomentan arreglos corruptos entre los empleadores y los sindicatos dominados por los empleadores. Utilizando el nuevo estatuto de la Colombia Británica como un estudio de caso, se evalúa la suposición que el requisito del consentimiento sindical a la derogación de normas esenciales asegura que la derogación refleja las preferencias de los trabajadores. Utilizamos dos fuentes empíricas de datos : los pactos colectivos acordada por un sindicato cercano a la patronal (la Asociación laboral cristiana de Canadá) y los pactos colectivos donde el sindicato no tenía ni la oportunidad ni la fuerza para oponerse a la derogación.

PALABRAS CLAVES : derecho laboral, Colombia Británica, proyecto de ley 48, pacto colectivo, derogación temporal 